\title{
НОМЫН ШҮҮМЖ
}

\section{ОХУ-ЫН НЭРТ МОНГОЛЧ ЭРДЭМТЭН В.В.ГРАЙВОРОНСКИЙН ХОЁР БУТЭЭЛИЙН ТУХАЙ}

\author{
Ц.Баатар \\ ШУА-ийн Олон улсын харилиааны хүрээлэнгийн \\ Эрдэм шинжилгээний тэргүүлэх ажилтан, профессор, \\ эдийн засгийн ухаань доктор (ScD). \\ E-mail хаяг: tsend_baatar@yahoo.com
}

Грайворонский Владимир Викторович бол Монгол судлалд 60 шахам жилийн ажил амьдралаа зориулж яваа ОХУ-ын нэрт монголч эрдэмтдийн нэг юм. Түүний судалгаанд Монголын шинэхэн түүх, Орчин үеийн Монголын улс төр, нийгэм-эдийн засгийн өөрчлөлт, Орос-Монголын харилцаа чухал байрь суурь эзэлдэг. Тэрбээр өнгөрсөн хугацаанд дээрх сэдвээр 130 гаруй судалгаа шинжилгээний бүтээл туурвижээ. Эртний анд, номын садан, нэрт Монгол судлаачын дээрх бүтээлүүдээс надад зориулж чинь сэтгэлийн үг бичиж бэлэглэсэн "Реформы в социальной сфере современной Монголии" /Москва, 2007/, “Изменения в уровне жизни населения Бурятии (Россия), Монголии и Внутренней Монголии (Китай) в конце XXначале XXI вв". /Лос-Анджелес, Улан-Батор. 2014/ нэгэн сэдэвт томоохон даацтай бүтээлүүдийг энд онцлон авч үзлээ.

\section{“Реформы в социальной сфере современной Монголии" /Москва, 2007/ нэгэн сэдэвт бүтээлийн тухай}

Монголын нийгмийн ардчилсан өөрчлөлтийн талаархи судалгаа гадаадын монголч эрдэмтэн, судлаачдын анхаарлыг зүй ёсоор 
татсаар ирсэн асар өргөн цар хүрээтэй сэдвийн нэг. Энэ чиглэлээр даацтай судалгаа хийсэн гадаадын монголч эрдэмтэдийн нэг нь Грайворонский Владимир Викторович юм.

Судлаач "Реформы в социальной сфере современной Монголии" /Москва, 2007/ бүтээлдээ ХХ зууны 90-ээд оны эхнээс Монголд ардчилсан өөрчлөлт өрнөж, зах зээлийн эдийн засагт шилжсэнээс хойшхи 15 жилийн дотор гарсан Монголын нийгмийн өөрчлөлтийг эрүүл мэнд, соёл боловсрол, шинжлэх ухаан, нийгмийн халамж үйлчилгээний жишээн дээр цогц байдлаар авч үзжээ. Эмпирик судалгаанд ашигласан эх сурвалж, статистикийн мэдээлэл нь 19902005 он хүртлэх хугацааг хамарч байна.

ЭнэхүҮ бүтээл 4 бүлэг, 17 зүйл, удиртгал, төгсгөл, англи товч агуулга гэсэн хэсгээс иж бүрдэл болох бөгөөд нийт 152 тал хуудастай.

Судлаач Монголын нийгэмд өнгөрсөн 15 жилд өрнөсөн өөрчлөлтийн явцад хийсэн шинэчлэл нь нийгэмд эерэг, сөрөг ямар үр дагвар авч ирсэн болохыг тал бүрээс нь задлан шинжилж үзээд дараах дүгнэлтүүд хийжээ.

Ардчилсан өөрчлөлтийн явцад улс төрийн тогтолцооны шинэчлэлийн үр дүнд шинэ үндсэн хуулиа баталж, олон намын систем бүрэлдэн, парламентын засаглал тогтсон зэрэг нааштай ахиц өрчлөлт гарч байгаа хэдий ч бүрэн шинэчлэл болоогүй, шинэ намууд төлөвшөөгүй, явуулж буй үйл ажиллагаа нь хангалтгүй завсрын үедээ байна. Өнөөгийн Монголын улс төрийн системийн хөгжлийн хөдөлгүүр болох намуудын үндсэн зөрчил нь гол хоёр намын засгийн эрхийн төлөөх тэмцэл болж, энэ бүхнээс үүдэн параментын засаглалтай байхуу ерөнхийлөгчийн засаглалтай байх нь дээр үY гэсэн хэлэлцүүлэг мэтгэлцээн үргэлжилж, улс төрийн намуудын тухай болон сонгуулийн хуулийг өөрчлөх тухай яриа үргэлжилж, авилга газар авч сонгогчдын санал худалдан авах зэрэг хууль зөрчих үзэгдэл гарч байгаa зэрэг сөрөг үзэгдлүүдтэй холбон авч үзсэн байна. 
Монголын эдийн засгийн суурь бүтцийг өөрчлөн шинэчлэх үйл явцыг тухайн үед төрөөс гаргасан хууль тогтоомж, авч хэрэгжүүлсэн арга хэмжээ, статистикийн мэдээ баримт болон монголын эрдэмтэн судлаачдын бүтээл, бусад арвин их эх сурвалуудыг өргөнөөр ашиглаж, харьцуулан судалж үзээд төвлөрсөн төлөвлөгөөт эдийн засгаас зах зээлийн эдийн засгийн хөгжлийн загварыг сонгосон 1990-2005 онд Монголын эдийн засаг гүн гүнзгий хямралд орсон. Энд дотоод, гадаад олон хүчин зүйл нөлөөлсөн. Сүүлийн жилүүдэд ДНБ хурдтай өсч байгаа ч энэ өсөлт нь тогтворгүй ихээхэн хэлбэлзэх хандлагатай байна гэсэн дүгнэлт хийжээ.

Монголын хүн ам зүйн талаарх статисикт үндэслэн дараах дүгнэлтэд хүрсэн байна. 1990-2004 онд хүн ам зүйн байдалд олон шалтгаан нөхцөл, хүчин зүйлийн улмаас харилцан адилгүй өөрчлөлт гарсан. Тухайлбал, 1990-ээд оны эхний системийн хурц хямралын үед хүн амын өсөлт удааширч, 90-ээд оны хоёрдугаар хагасаас тогтмол өсч, эх нялхасын эндэгдэл буурч, дундаж наслалт 65 хүрч, хөдөөнөөс хот чиглэсэн шилжих хөдөлгөөн газар авч, монголын нийгмийн бүтцэд ихээхэн өөрчлөлт гарч, хувийн сектор эрчимтэй хөгжиж, нийгмийн-ангийн бүтэц солигдож улсын секторт ажиллагсад буурч, хувийн секторт ажиллагсад өсөн нэмэгдэж, ДНБ-ий 80 хувь нь энэ секторт ногдож, нийгмийн болон хүн амын шилжилт хөдөлгөөн өсөн нэмэгдэж, ядуурал, ажилгүйдэл зэрэг сөрөг үзэгдэл газар авч байгаа нь шийдвэрлэвэл зохих тулгамдсан асуудлын нэг гэж үзжээ.

ЭнэхүҮ нэгэн сэдэвт бүтээлийг бүхэлд нь авч үзвэл өнгөрсөн 15 жилийн хугацаанд Монголын нийгмийн өөрчлөлтийг дотоод гадаад орчинтой нь холбон авч үзээд орчин үеийн Монголын нийгмийн шинэчлэлийн үйл явц нь өмнөх социалист нийгмийн тогтолцооноос ардчилал, зах зээлийн эдийн засгийн үндсэн зарчимд тулгуурласан шинэ бүтцэд шилжих шилжилтийн эхний шатандаа явж байгаа тул хуучин шинийн, нийгмийн шинэ бүлэг давхараа хооронд зөрчилтэй, нийгэм, улс төрийн үйл явц тогтворгүй хэвээр байна гэсэн гол дүгнэлт хийжээ. 
Олон улсын байгууллагын зүгээс энэ салбарын шинэчлэлд зориулан олгож ирсэн зээл тусламж нь тухайн цаг үеийн хүндрэлийг даван туулахад зохих үр дүнгээ өгсөн тусламж дэмжлэг болсон гэж дүгнэсэн байна. Түүнчлэн дээрх хугацаанд Монгол Оросын харилцаанд гарсан өөрчлөлт, түүний эерэг сөрөг үр дагаврыг ч хөндөн судалж Орос нь Монголын худалдаа эдийн засгийн гол түнш, донор орны нэг хэвээр байж хөрш, найрамдалт орны хувьд өөрийн хувь нэмрээ оруулсаар ирсэн хэмээн дүгнэсэн байна.

Нэрт монгол судлаач монголын нийгмийн өөрчлөлтийг шилжилтийн үедээ яваа хөгжиж буй орнуудтай харьцуулан шинжилж үзээд нийгмийн салбарын шинэчлэлийн суурь нь зөв тавигдсан, цаашдаа нийгэм эдийн засаг тогтвортой хөгжих боломж нөхцөл бүрдсэн гэж үнэлж дүгнэсэн олон улсын экспертүүдтэй санал нэгтэй байна гэсэн байна.

Түүнчлэн Орос, Монголын бүх талыг хамарсан найрамдалт харилцаа нь Монгол Улсын нийгэм эдийн засгийн хөгжлийн тулгамдсан асуудлыг богино хугацаанд шийдвэрлэхэд чухал ач холбогдолтой хэмээн цохон тэмдэглэжээ.

Манай нийгмийн амьдралын салбарын өөрчлөлт янз бүрийн цар хүрээтэй өрнөж байгаа энэ цаг үед бид алдаж онож яваад хүрсэн үр дүндээ эргэн шинжилгээ хийж, цаашдын зорилтоо тодорхойлоход бидний анхаарууштай олон сайхан санаа байгааг энд цохон тэмдэглэх нь зүйд нийцэх биз ээ.

ОХУ-ын нэрт монголч Грайворонский гуайн энэхүҮ бүтээл Монголын нийгмийн өөрчлөлтийн 15 жилийн үйл явцад дүн шинжилгээ хийж, суурь өөрчлөлтийг дагаад нийгмийн амьдралын бусад салбаруудад гарч буй ахиц, нэвтэрч буй шинэ зүйлийг өнгөн талаас нь тоочих бус цаана нь нуугдаж буй сөрөг үр дагаврыг олж харсан, түүнийг засаж залруулах талаар өөрийн санаа бодлоо илэрхийлсэн чамбай бүтээл болжээ. 


\section{“Изменения в уровне жизни населения Бурятии (Россия), Монголии и Внутренней Монголии (Китай) в конце XX- начале XXI вв”. /Лос-Анджелес, Улан-Батор. 2014/ нэгэн сэдэвт бүтээлийн тухай}

Монголч эрдэмтдийн анхаарал сонирхолыг зүй ёсоор татсаар ирсэн, олон талын судалгаа-мэдээлэл шаардах энэхүү хүндхэн сэдвийг ОХУ-ын нэрт монголч Грайворонский Владимир Викторович анх удаа сонгон авч, нэгэн сэдэвт даацтай томоохон бүтээл туурвижээ. ЭнэхүҮ бүтээлд Монгол Улс болон ОХУ-ын Буриад, БНХАУ-ын Өвөр Монголын хүн амын амьдралд гарч буй өөрчлөлтийг XX зууны далаад оноос XXI зууны эхний нэгэн арваны хооронд тухайн улс орнуудад өрнөсөн үйл явц, нийгэм-эдийн засгийн хөгжлийг дагалдан хүн амын амьдралын түвшинд гарсан өөрчлөлтийг улс орнуудын ДНБ-ий өсөлт, хүн амын орлого зарлагын дундаж, үйлдвэрийн болон үйлдвэрийн бус бараа таваарын хэрэглээ, амьдралын нөхцөл, хүний хөгжлийн түвшин, ядуурлын асуудал зэрэг амьдралын түвшний үндсэн үзүүлэлтүүдээр харьцуулан судалж нэгтгэн дүгнэсэн байна.

Монгол судлаачдын анхаарал сонирхол татсан энэхүу бүтээл 5 бүлэг,14 зүйл, удиртгал, төгсгөл гэсэн хэсгээс иж бүрдэл болох бөгөөд нийт 284 тал хуудастай.

Орос, Монгол, Хятадад өрнөсөн нийгмийн хувьсал өөрчлөлт, хөгжлийн замын сонголтын ялгаа, орон тус бүрийн онцлог, нөхцөл байдлыг тухайн цаг үеийн гадаад орчинтой нь нягт холбон түүнд нөлөөлсөн гол хүчин зүйлүүдийг харьцуулан судалж үзсэн байна. Тухайлбал, Орос оронд 1991-1996 онд явуулсан системийн өөрчлөлтөөр улсын өмчийг хувийн өмчид шилжүүлэх, үнийг чөлөөлж улсын гадаад худалдааны монополь эрхийг халж, мөнгөзээлийн хүрээ, татвар санхүүгийн системийг үндсээр нь өөрчилсөн. Ингэснээр үйлдвэрлэл уналтанд орж, нийтийг хамарсан ажилгүйдэл, гипер инфляцид нэрвэгдэж хүн амын амьдралын түвшин доройтож, ядуурал өсөн нэмэгдэж, авилга хээл хахуул газар авч, олигархууд 
төрөн гарах үүд хаалга нээгдсэн байна. 1990-2001 оны хооронд хүн амын бодит мөнгөн орлого 51.6 хувиар буурчээ. Дээрх нөхцөл байдлын улмаас хүн ам нутаг орноо орхин явах сөрөг үзэгдэл эрчимтэй явагджээ. Тухайлбал, 1990-ээд оноос Оросын хүн ам жил бүр 700-900 мянгаар буюу өдөрт 2.5 мянган хүнээр хорогдож байсан аж. 2000-2008 онд эдийн засаг тогтворжиж жилийн дундаж өсөлт 6-7 хувьд хүрснээр хүн амын бодит орлого 2 дахин нэмэгдэж, ядуурлын түвшин 2 дахин буурсан байна. Ийнхүү Орос орон дэлхийн хамгийн том эдийн засагтай 10 орны нэгэнд эргэн орсон болохыг бодит эх сурвалж, статистик мэдээлэлд тулгуурлан дүгнэсэн байна.

Хөгжлийн шинэ загвар сонгон улс төр, эдийн засгийн өөрчлөлтийг нэгэн зэрэг хийсэн Монгол Улсын хувьд нийгмийн өөрчлөлтийн эхэн үеийн үйл явц Орос оронтой адил төстэй байсныг олон жишээ баримтаар харуулжээ. Тухайлбал, үйлдвэрлэл уналтад орж ажилгүйчүүдийн арми бий болж, амьдрахын эрхээр ганзагчид хэмээх нийгмийн шинэ ажиллах хүч бий болж Хятад, Сингапур, Хонконгоос бараа зөөж Орос болон Европын орнуудад борлуулж амьдралаа залгуулж, аажмаар хуримтлалтай болж, жижиг дунд үйлдвэр эрхэлж, өмч хувьчлалд оролцож, томоохон үйлдвэр аж ахуйн газруудыг хувьчилж авснаар шинэ хөрөнгөлөг бизнесменүүд төрөн гарч, 2012 оны байдлаар 1000 хүн ам тутамд ногдох саятнуудын тоогоороо дэлхийд 4 дүгээр байр эзлэх болсныг олон улсын эх сурвалжаас эш татан дурдсан байна. Нөгөө талдаа хүн амын ядуурлын түвшинээс доогуур амьдарч байгаa хувь хэмжээ буурч байгаа ч дорвитой ахиц гараагүй, ажилгүйдэл их байгаагийн улмаас залуучууд нь гадаадад гарч ажиллах нь элбэг болохыг баримтаар эш татсан байна.

Хятадын эдийн засгийн шинэчлэл 1978 оноос эхэлж өнгөрсөн 30 гаруйхан жилийн хугацаанд дэлхийн хүчирхэг гүрэн болж 1978-2011 он хүртлэх хугацаанд ДНБ дундажаар 9-10 хувиар өсч, Америкийн дараа орох болсон. Гадаад худалдаа 20.6 тэрбум ам доллараас 2012 он гэхэд 3 их наяд 866.8 тэрбум ам.долларт хүрч, гадаадын хөрөнгө оруулалт мөн онд 111.7 тэрбум ам.доллар, хятадын гадаадад оруулсан 
хөрөнгө оруулалтын хэмжээ 77.2 тэрбум ам.доллар болсон зэрэг ҮзүҮлэлтийг эш татаад энэхүҮ өсөлт нь нийгмийн хүрээнд илүҮ таатай нөлөө Үзүүлсэн болохыг дараах статистикаар харуулжээ. 1978 онд хотын хүн амын орлого 343 юань байсан бол 2012 онд 24.6 мянган юань, хөдөөгийнх 133.6- 7.9 мянган юань болж, бүх нийтийг хамарсан ядуурлыг халж, 1.3 тэрбум хүний амьдралын түвшинг дээшлүүлж чадсан нь хятадын нээлттэй хаалганы бодлого, стратеги төлөвлөлт нь удаан хугацаанд тотвортой хэрэгжиж ирсэний бодит үр дүн гэж үзсэн байна.

Зохиогч ийнхүҮ Орос, Монгол, Хятадын нийгэм-эдийн засгийн хөгжлийн бодлогод гарсан шинэчлэлт өөрчлөлтийн ерөнхий чиг хандлагыг макро түвшинд авч үзээд дээрх өөрчлөлт шинэчлэлт Оросын Буриадын Бүгд найрамдах улс, Хятадын Өвөр Монголын Өөртөө Засах орны нийгэм-эдийн засгийн хөгжлийн асуудлыг газар зүй, хүн ам зүйн 1990-2012 оны статистик үзүүлэлтүүдээр харьцуулан судалсан байна.

Буриадын хүн ам 2013 оны 1 дүгээр сарын 1-ний байдлаар 971.8 мянга, түүний 64.9 хувь нь орос, 29.5 хувь нь буриад, цөөн тооны татар, украйн, соёд, эвэнк зэрэг үндэстэн оршин суудаг аж. Хотод хүн амын 58.8 хувь, хөдөөд 41.2 хувь оршин суух бөгөөд хүн амын 21.3 хувь 16 хүртлэх насны, 61.9 хувь хөдөлмөрийн насны, 16.8 хувь нь тэтгэврийн насных юм байна. 2002 оны хүн амын тооллогоор ОХУ-ын хэмжээнд 461.4 мянган буриад үндэстэн бүртгэгдсэний 300 мянга буюу 60 хувь нь Буриад улсад оршин сууж буй аж. Буриадад 2000 он хүртэл их уналт, системийн гүн хямрал үргэлжилж хүн амын тал гаруй буюу 53.5 хувь нь ядуурсан байна. Бүс нутгийн хэмжээнд үйлдвэрлэлийг сэргээн хөгжүүлэх талаар шат дараатай арга хэмжээ авсаны үр дүнд ядуурал 2005 онд 32.6 хувь, 2007 онд 24.4 хувь, 2010 онд 19.8 хувь болж буурсан байна. 2007-2011 онд амьдралын доод түвшиний хангамж 4148 рубль байснаа 6311 рубль болж өссөн, 2000-2012 онд хүн амын дундаж мөнгөн орлого 10.5 дахин, дундаж хэрэглээ 9.4 дахин, цалин 12 дахин, тэтгэвэр 9.6 дахин нэмэгдсэн хэдий ч ядуурал Оросын дундажаас 11-13 хувиар өндөр байгаа аж. 
ОХУ-ын нэрт монголч эрдэмтэн В.В.Грайворонскийн хоёр бүтээлийн тухай

Буриадын хүн амын амьдралын түвшний 1990-2012 оны динамик Үзүүлэлтүүдээс үзэхэд жил ирэх бүр бага ч гэсэн ахиц гарч буй аж. Тухайлбал, 1995 онд сарын мөнгөн орлого 378.8 рубль байсан бол 2012 онд 17223 рубль, сарын зарлага нь 288,1-17027 рубль, ажиллагсадын сарын дундаж цалин 503.8-22900 рубль, тэтгэвэр 234.1-7709 рубль, тэтгэврийн хүний тоо 217-246 мянга, ядуурал 54.320.9 хувь, өргөн хэрэглээний мах махан, сүY сүүн болон гурилан бүтээгдэхүүн, хүнсний ногооны нэмэгдсэн байна.

Судлаач ӨМӨЗО-ны нийгэм-эдийн засгийн хөгжлийг 1990-2010 оны статистик үзүүлэлтүүдийг ашиглан нэлээд өргөн цар хүрээнд авч үзсэн байна. Тус орны хүн ам 2008 оны байдлаар 24.4 сая үндэсний цөөнх 4.9 сая буюу хүн амын 20.7 хувийг эзлэх бөгөөд дийлэнхи хувь нь монголчууд гэсэн байна. Хятадын бусад муж, өөртөө засах орнуудад тархан суугаа монголчууд нийлээд 5.8 сая гэсэн хятадын статистикийг эш татан дурджээ. Түүнчлэн 1984-2006 оны хооронд өөртөө засах орны монголчууд 2.68 саяар нэмэгдэж 4.2 сая болж, монгол хүн амын жилийн дундаж өсөлт 2.6 хувьд хүрсэн гэсэн манай нэртэй хятадач эрдэмтэний нэг Л.Бэгзжав агсаны судалгааг эш татан өгүүлжээ. Монгол хүн амын энэ өсөлт нь хятадын үндэсний цөөнхийн талаар явуулсан нааштай бодлогын үр дүн гэж үзсэн байна. Өнөөгийн байдлаар 4.2 сая монголчуудын 2.8 сая орчим нь газар тариалан эрхэлж, 1.4 сая нь мал аж ахуй эрхэлж уламжлалт нүүдлийн хэлбэр алдагдсан гэсэн Өвөр монголын судлаач Ч.Энхээгийн судалгааг эш татсан байна.

Хятадын шинэчлэлийн явцад гарсан өөрчлөлтийн нэг нь үндэстний цөөнхийн талаар явуулах шинэ бодлогоо 1982 онд үндсэн хуулиндаа суулгаж, 1984 онд үндэсний автономит районы тухай хууль гаргасан. Улмаар 1990 оны сүүлчээр үндэсний боловсон хүчин бэлтгэх стратегийн чиглэлийг тодорхойлж, үндэсний өөртөө засах орнуудын төрийн албанд хятад болон хятад бус үндэстнүүдийг тэнцүҮ харьцаатай ажиллуулах зорилт тавьж, тэдний боловсролын түвшинг дээшлүүлэх, мэргэшүүлэх талаар системтэй арга хэмжээ авснаар хятадын хэмжээнд 2.6 сая үндэсний цөөнх төрийн албанд 
ажиллах болсон байна. Өвөр Монголд энэ бодлогын үр дүнд төрийн албанд ажиллах монголчуудын квот нэмэгдсэн байна.

Өвөр Монголын хүн амын амьдралын түвшний 1978-2008 оны динамик үзүүлэлтүүдээс үзэхэд хотын хүн амын жилийн дундаж орлого 1978 онд 301 юань байсан бол 2008 онд 14431 юань, газар тариалан мал аж ахуйд ажиллагсад 131.4-4656 юань болж өссөн байна. Хүн амын амьдралын түвшний бусад үзүүлэлтүүд ч өсөн нэмэгдсэн байна. Хүн амын амьдралын түвшний хятадын стандартаар авч үзвэл Өвөр Монгол доогуурт ордог байна. Ялангуяа хөдөөд энэ байдал илүү буй аж. Аж үйлдвэр, уул уурхай эрчимтэй хөгжиж буйн улмаас малын бэлчээр хумигдаж сөрөг үзэгдэл гарч буй аж.

Зохиогч гурван орны хүний хөгжлийн чадавхийн индекс 20002010 оны хооронд хэрхэн өөрчлөгдсөн болохыг шинэ аргачлалын дагуу үндсэн 5 үзүүлэлтээр харьцуулан судалж үзсэн байна. Хүний хөгжлийн ерөнхий индекс 2000 онд Оросод 0.781, Хятадад 0.726, Монголд 0.665 байсан бол 2010 оны байдлаар 0.782, 0.689, 0.657, хүн амын дундаж наслалт 66.1-68.5, 70.2-73.2, 62.9-68.2 бичиг үсэгт тайлагдсан байдлаар 99.6-99.6, 84.1-94.3, 98.9-97.4 ерөнхий болон их дээд сургуульд хамрагдсан байдлаар 78-85 хувь, 73-70 хувь, 5883 хувь хүн ам дутамд ногдох ДНБ 8377-14199, 3976-6819, 17833620 ам.доллар болсон байна. Дэлхийн хэмжээнд авч үзвэл 2010 оны байдлаар Орос 55, Хятад 101, Монгол 108-д орж буй аж.

Нэрт монгол судлаач В.В.Грайворонскийн Монгол Улс болон монголчууд аж төрөн сууж буй Оросын Буриад, Хятадын Өвөр Монголын нийгэм-эдийн засгийн хөгжлийн явцтай уялдан хүн амын амьралын түвшингийн өөрчлөлтийг цогц байдлаар харьцуулан судалсан энэ бүтээл мөнхийн хөрш гурван улсын нийгэм, улс төрийн тогтолцоо, хөгжлийн бодлого, стратеги зэрэг нь харилцан адилгүй, хүн амын амьдралын түвшинг хэмжих хэмжүүр, стандарт өөр өөр, өөрийн гэсэн үнэмлэмжтэй, өвөрмөц онцлогтой хөгжиж байгаа өнөөгийн нөхцөлд орон тус бүрийн нийгэм-эдийн засгийн хөгжлийн бодлого хүн амын амьдралын түвшинд хэрхэн нөлөөлж ямар 
ОХУ-ын нэрт монголч эрдэмтэн В.В.Грайворонскийн хоёр бүтээлийн тухай

өөрчлөлт гарч, хэрхэн аж төрж буй ерөнхий дүр төрх, түүнд нөлөөлж буй эерэг сөрөг хүчин зүйлүүдийг нээн харуулж чадсан, монгол судлал төдийгүй бүс нутаг судлалд жинтэй хувь нэмэр оруулсан даацтай бүтээлийн нэгэнд зүй ёсоор орно. 